BOTANICA

ISSN 2538-8657

2020, 26(2): 116-125

\title{
VARIATION IN GROWTH RESPONSE OF COASTAL DUNE-BUILDING GRASS SPECIES AMMOPHILA ARENARIA AND LEYMUS ARENARIUS TO SAND BURIAL
}

\author{
Gederts IEvinsh*, Una Andersone-Ozola
}

University of Latvia, Faculty of Biology, Department of Plant Physiology, Jelgavas Str. 1, 1004 Rīga, Latvia

*Corresponding author. E-mail: gederts.ievins@lu.lv

\begin{abstract}
Ievinsh G., Andersone-Ozola U., 2020: Variation in growth response of coastal dune-building grass species Ammophila arenaria and Leymus arenarius to sand burial. - Botanica, 26(2): 116-125.

Ammophila arenaria and Leymus arenarius are dune-building grass species native to European seacoasts. The present study aimed to compare growth responses to the sand burial of A. arenaria and L. arenarius from coastal habitats of the Baltic Sea, when the intensity of sand accretion was relatively low under controlled conditions. Plants were grown from seeds collected from natural coastal habitats, transplanted into individual containers, buried in the sand at different depths in the rapid shoot elongation stage, and further cultivated (11 or 9 weeks) in an automated greenhouse. Burial in sand significantly stimulated the growth of shoots of A. arenaria, the effect was earlier at high burial intensities (46 and 60\%) and was evident ten days after the start of treatment. Both shoot and root dry mass increased for plants buried at 13\%; however, increased burial depth (37, 46 and $60 \%$ ) resulted in a significant increase in root biomass. In comparison, shoot biomass decreased significantly at the highest burial intensity $(60 \%)$. For L. arenarius, there was no direct dependence of shoot elongation rate on burial depth. There was a tendency for increased elongation growth and biomass allocation to leaf sheaths despite a decrease in total shoot mass. Most strikingly, root biomass decreased with sand burial in parallel with increased burial depth up to $21 \%$ intensity. In conclusion, although both grass species showed a positive shoot growth response to moderate sand burial intensity, differences in individual responses at the morphological and physiological level indicate the existence of different genetically based adaptation strategies.
\end{abstract}

Keywords: Ammophila arenaria, coastal dunes, grass species, growth response, Leymus arenarius, sand burial.

\section{INTRODUCTION}

Coastal dune habitats around the world are highly dynamic biogeographic and ecological systems maintaining substantial biological diversity (Provoost et al., 2011; KeiJsers et al., 2015; CicCARELli \& BacAro, 2016). Sand accretion in coastal habitats, including beaches and dunes, is among environmental factors having a significant effect on plant species distribution as well as growth and reproduction of individual coastal plants (Maun \& Perumal, 1999; Gilbert et al., 2008; FidALGO et al., 2014). Native sand dune species possess a high tolerance to burial by sand, being able to complete generative reproduction even after almost complete burial (IEvinsh, 2006).
Several coastal grass species represent dunebuilders, having both excellent burial tolerance and the ability for stimulated growth under conditions of sand accretion. Two typical representatives of this group are Ammophila arenaria (L.) LinK and Leymus arenarius (L.) Hochst., native to European seacoasts (Bond, 1952; HuIskes, 1979). Both species are specifically associated with coastal habitats, indicating the presence of specific adaptations giving an advantage in prevailing conditions of these habitats. Both plants represent umbrella species of the European protected habitat EUH 2120 "Shifting dunes along the shoreline with Ammophila arenaria (white dunes)" (Laime, 2013).

From the point of population biology, A. arenaria 
has been characterised as a species with high phenotypic plasticity. Plants growing under optimal and unfavourable environmental conditions were compared; the measured difference in plant height was double, but the difference in total dry biomass exceeded 30 times (GrAY, 1985). In contrast, the existence of a mixed genetic polymorphism and plasticity can be proposed for $L$. arenarius based on differences in populations of coastal and inland Iceland (GREIPSSON \& DAVY, 1996). However, in the case of the related species Leymus mollis, it has been shown that the differences among the different populations in subarctic dunes are caused by the environmental rather than genetic factors (IMBERT \& Houle, 2000). While both species exhibit clonal growth, their clonal strategy shows significant differences. A. arenaria plants can develop vertically expanding rhizomes, resulting in dense clonal expansion, but $L$. arenarius plants rely mostly on the horizontal spread of rhizomes, resulting in a relatively wider expansion of genets (PAVLIK, 1983; REIJERs et al., 2020).

Recent studies have shown renowned interest in the role of the biology of dune building grasses in ecology and coastal dune conservation (REIJERS et al., 2019, 2020). So far, no studies have directly compared burial responses of $A$. arenaria and $L$. arenarius. Therefore, the present study aimed to compare growth responses to the sand burial of $A$. arenaria and L. arenarius from coastal habitats of the Baltic Sea, where the intensity of sand accretion is relatively low. It was specifically intended to find out whether there are any differences in sand burial responses, possibly related to specific growth forms of the particular species.

\section{MATERIALS AND METHODS}

\section{Seed source and plant establishment}

Seeds of $A$. arenaria were collected in white dunes on the coast of the Baltic Sea near Ventspils, Latvia in August 2017. Seeds of L. arenarius were collected in white dunes on the coast of the Gulf of Riga near Jūrmala, Latvia in August 2018. Seeds were dried for one month under laboratory conditions and then stored at $4{ }^{\circ} \mathrm{C}$ in paper bags. Before planting, seeds were surface sterilised in 50\% commercial bleach (Ace, Procter \& Gamble) for $10 \mathrm{~min}$ followed by an active rinse with deionised water (five times for $5 \mathrm{~min}$ ). After imbibition in deionised water for $4 \mathrm{~h}$, seeds were planted in sterilised $200 \mathrm{~mL}$ plastic containers in a mixture of autoclaved commercial garden soil (Biolan, Finland) and quartz sand (1:1, $\mathrm{v} / \mathrm{v}$ ) mixed with sterile deionised water. Containers were placed in a growth cabinet with a thermoperiod $15 / 20^{\circ} \mathrm{C}$ (night/day) in conditions of $12 \mathrm{~h}$ photoperiod (photon flux density of photosynthetically active radiation $40 \mu \mathrm{mol} \mathrm{m}^{-2} \mathrm{~s}^{-1}$ ). When seedlings formed second true leaf, they were individually transplanted to square plastic containers $(11.3 \times 11.3 \times 21.5 \mathrm{~cm}, 2 \mathrm{~L})$ filled with $1 \mathrm{~L}$ of garden soil and quartz sand mixture $(1: 1, \mathrm{v} / \mathrm{v})$. Containers were placed in an experimental automated greenhouse (HortiMax, Netherlands) with supplemented light from Master SON-TPIA Green Power CG T 400 W (Philips, Netherlands) and Powerstar HQI-BT 400 W/D PRO (Osram, Germany) lamps $\left(380 \mu \mathrm{mol} \mathrm{m} \mathrm{m}^{-2} \mathrm{~s}^{-1}\right.$ at the plant level), $16 \mathrm{~h}$ photoperiod, day/night temperature $23 / 15^{\circ} \mathrm{C}$, relative air humidity 60 to $70 \%$. Position of individual plants was randomly changed every week.

\section{Treatment and cultivation}

Burial was performed two weeks after transplantation of seedlings in the active phase of shoot elongation to individual containers. The treatment was carried out as a single burial episode, using autoclaved pure quartz sand (Saulkalne S, Latvia). Five burial depths were used for A. arenaria: 13, 23, 37, 46 and $60 \%$, respectively, to plant height (Fig. 1A). As it was initially expected that burial tolerance of L. arenarius would be relatively lower, seedlings were covered with sand up to $7,13,21$ and $31 \%$ of plant height (Fig. 1B). To achieve deeper burial than the height of the individual container, containers of the same size without bottom were placed over the substrate and filled with sand to the indicated depth. Unburied plants $(0 \%)$ were used as control. In the case of $A$. arenaria, two controls were used, one with plants in $2 \mathrm{~L}$ containers as for other treatments (shaded control, $\left.0^{*}\right)$, and another in smaller $(1.2 \mathrm{~L})$ containers. For $A$. arenaria, additional shaded treatment $\left(25^{*}\right)$ at $25 \%$ burial intensity was performed by placing empty $2 \mathrm{~L}$ container over the substrate (Fig. 1A). For each burial treatment, ten plants were used.

Soil moisture of control (unburied) plants was monitored with $\mathrm{HH} 2$ moisture meter, equipped with WET-2 sensor (Delta-T Devices, UK) daily not al- 

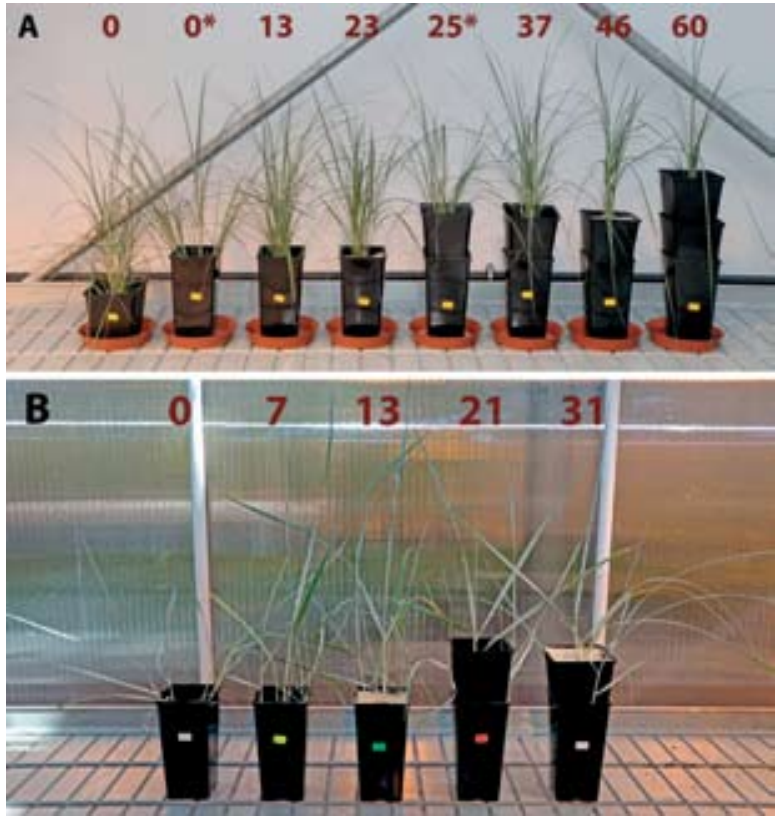

Fig. 1. Examples of Ammophila arenaria (A) and Leymus arenarius (B) plants in experimental sand burial treatments. Numbers indicate burial intensity in percentages from the height of the initial seedlings. The additional shaded treatments $0^{*}$ and $25^{*}$ were used for Ammophila arenaria

lowing the decrease of substrate moisture lower than $60 \%$ water holding capacity. Plants were watered from the bottom using equal amounts of deionised water for all treatments. Once a week plants were fertilised from the bottom of the containers with a Kristalon Green Label fertiliser (NPK 18-18-18 with micronutrients; Yara International, Norway) solubilised in deionised water $\left(150 \mathrm{~g} \mathrm{~L}^{-1}\right)$, with $5 \mathrm{~mL}$ of stock solution per L, $200 \mathrm{~mL}$ of the final fertiliser per container.

\section{Measurements}

Plant growth was periodically monitored as an increase in the height of the longest leaf within 11 and 9 weeks for A. arenaria and L. arenarius, respectively. At the end of the experiment, individual plants were separated from the substrate, and morphological parameters were measured. $A$. arenaria plants were measured for the number of tillers, the final shoot height, and the fresh and dry mass of shoot above the burial, the shoot below the burial, the roots within burial, and the roots in the initial soil volume. The number of leaves, the final shoot height, the length of the leaf sheaths, the fresh and dry root mass of the flag leaf, other leaf sheaths and other leaf blades of $L$. arenaria plants were estimated. The dry mass was determined by drying the tissues to constant mass in an oven at $60^{\circ} \mathrm{C}$.

\section{Data analysis}

Data analysis was performed using KaleidaGraph (v. 4.1, Synergy Software). Growth data were analysed by one-way ANOVA, followed by Fisher's LSD test. Student $t$-test was used to estimate statistically significant differences for morphological data between individual treatments $(p<0.5)$.

\section{RESULTS}

Treatment of $A$. arenaria plants was performed during the active shoot elongation phase, which con-
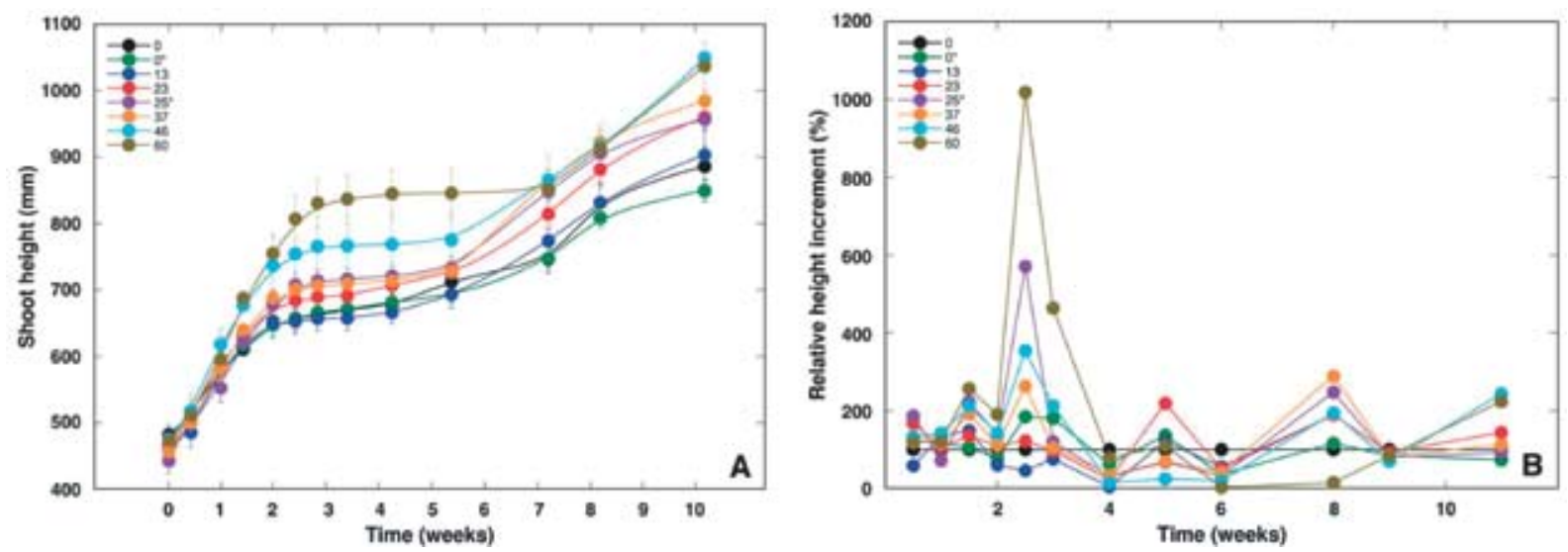

Fig. 2. Changes of shoot height in time as a response to sand burial at various depths of Ammophila arenaria plants (A). Data are means \pm SE of ten individual plants. Changes in relative height increment of Ammophila arenaria shoots due to sand burial at various depths (B). Data are means of ten individual plants. $0 *$ and $25^{*}$ present the additional shaded treatments 

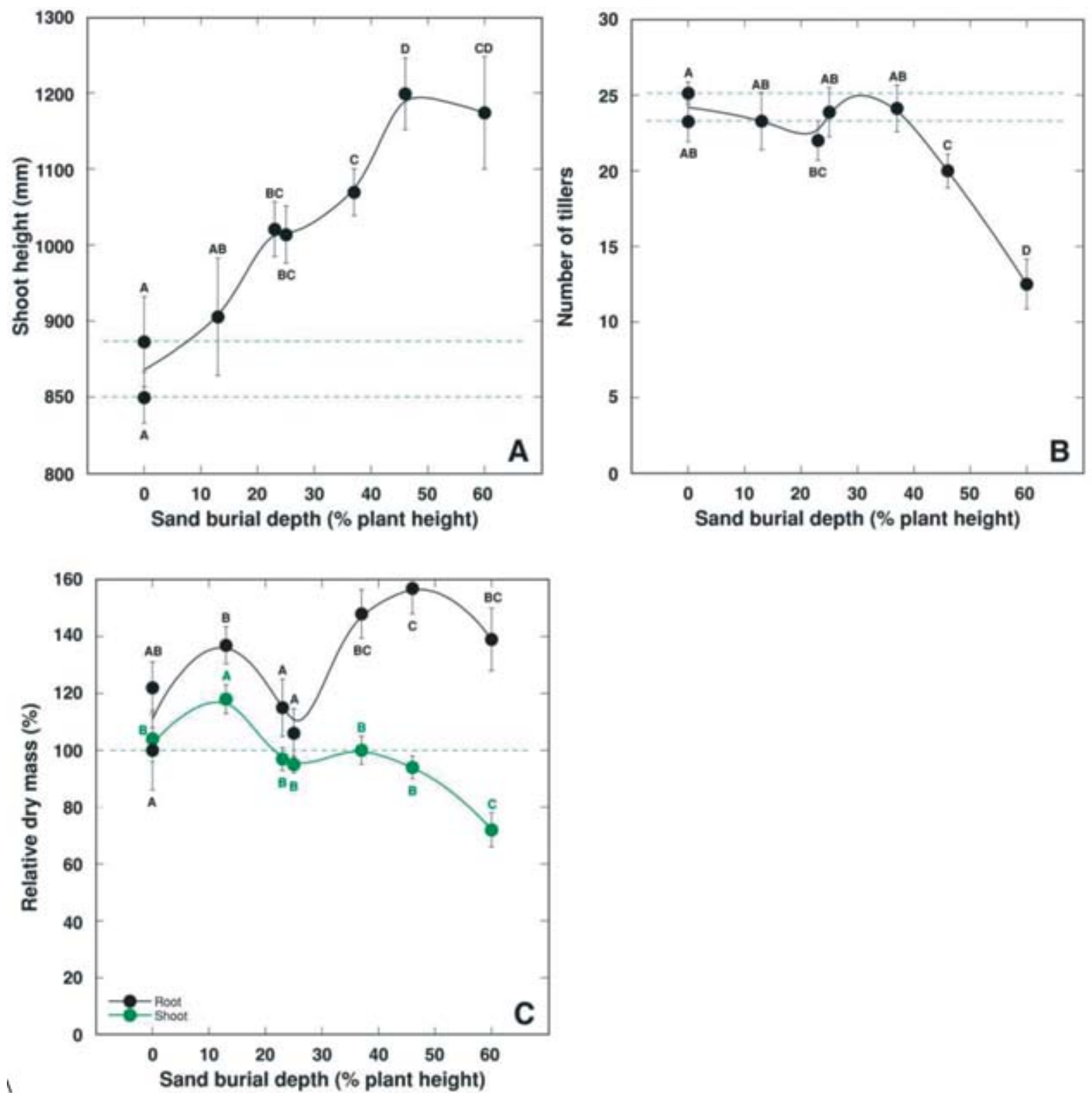

Fig. 3. Effect of sand burial depth on final shoot height (A), number of tillers (B), and relative dry mass of shoots and roots (C) of Ammophila arenaria plants. Data present the means \pm SE of ten individual plants. Different letters indicate statistically significant differences

tinued for 15 days, followed by a minimal elongation phase of about 20 days and followed by a slower growth phase (Fig. 2A). The effect of burial depth on shoot elongation was highly statistically significant $(\mathrm{F}=25.90, p<0.0001)$. Positive growth response to sand burial in shoots of $A$. arenaria was pronounced more early at high burial depth (46 and 60\%) and was evident ten days after the start of the treatment (Fig. 2A; $p<0.05$ ). The growth rate of individual plants was extremely variable and mean shoot increment values did not follow the recognisable pattern (Fig. 2B), with no statistically significant effect of burial depth $(\mathrm{F}=0.34, p=0.93)$. During the minimum elongation phase, shoot length was relatively proportional to the degree of burial. Still, during the second elongation phase starting from six to seven weeks, initial differences between plants with moderate and high burial treatments partially levelled off. 
At the end of the experiment, shoot height increased proportionally with an increase in burial depth up to $47 \%$ (Fig. 3A). There were no statistically significant differences between the two control treatments (with or without additional shading) as well as between the two identical treatments with or without additional shading (23 and $25 \%$ ).

The number of shoots of $A$. arenaria plants initially did not change with burial, but significantly decreased from $47 \%$ burial depth (Fig. 3B). Both shoot and root dry mass increased for plants at $13 \%$ burial (Fig. 3C). Increased burial depth $(37,46,60 \%)$ resulted in a significant increase in root biomass, but shoot biomass significantly decreased at the highest burial intensity $(60 \%)$. Despite a substantial increase in shoot height with increased burial intensity, the proportion of biomass of unburied shoot part nearly linearly decreased (Fig. 4). Increase in total root biomass at high burial intensity was clearly due to adventitious root development in the buried part of the plant. Still, the biomass of roots in initial soil volume decreased.

Burial treatment of $L$. arenarius plants was also performed within a phase of active shoot elongation (Fig. 5A). However, there was no direct dependence of shoot growth on burial depth $(\mathrm{F}=0.62, p=0.65)$. Changes in relative height increment over time were affected by burial depth, but the effect was not sta-

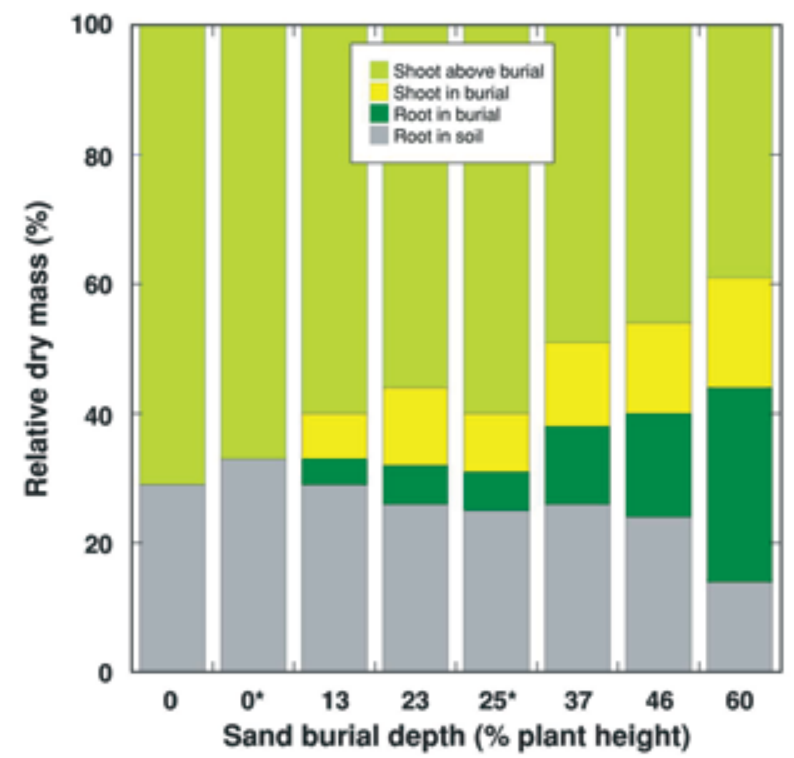

Fig. 4. Relative distribution of dry mass in different root and shoot parts of Ammophila arenaria buried in sand at different depths. $0 *$ and $25^{*}$ present the additional shaded treatments tistically significant $(\mathrm{F}=2.15, p=0.10)$ (Fig. 5B). Increase in elongation rate during the 1st week was evident for all burial treatments (Fig. 5B). Further, the rate of shoot elongation decreased proportionally at a burial depth of $7-21 \%$, but started to increase in treatment at $31 \%$ depth and, a week later, also for plants at other burial depths. After week four, the elongation rate for all burial intensities except the highest equilibrated and continued to decrease, but for $31 \%$ burial elongation was considerably higher until the end of the experiment. Statistically significant $(p<0.05)$ differences in shoot elongation dynamics were evident between control plants at 7, 13, and $31 \%$ burial depths. As a result, final shoot height was significantly higher than that in control plants only for 21 and $31 \%$ burial treatments, but no burial depth-dependent differences were found between all burial intensities (Fig. 6A). Besides, increased elongation and biomass allocation in the leaf sheaths were observed, despite the trend of decreasing total shoot mass (Fig. 6B). Most strikingly, the root biomass decreased with increased sand burial depth up to $21 \%$ intensity.

$L$. arenarius roots under non-buried conditions formed a larger part of plant biomass $(>80 \%$; Fig. 7). The increased biomass allocation to leaves, especially leaf sheaths, was particularly pronounced when analysing the relative distribution of biomass between plant parts (Fig. 7). Due to the inhibition of root growth, the relative mass of leaf lamina and flag leaf also increased (Fig. 7).

\section{DISCUSSION}

It has been argued that $L$. arenarius is so-called obligate-buried species, with plant vigour declining under conditions of stabilised dunes (GREIPSSON \& DAvY, 1994). Similarly, it has been shown that under conditions of stabilised dunes, A. arenaria stands deteriorate with time and eventually disappear completely (van der Putten \& Peters, 1995). Moreover, Ammophila breviligulata, a morphologically similar foredune plant from the Atlantic coast of North America, showed degeneration in the absence of sand accumulation (SELISKAR, 1994). One of the theories explaining the phenomenon is related to the increased availability of mineral nutrients as natural beach sand usually contains phosphorus and potassi- 

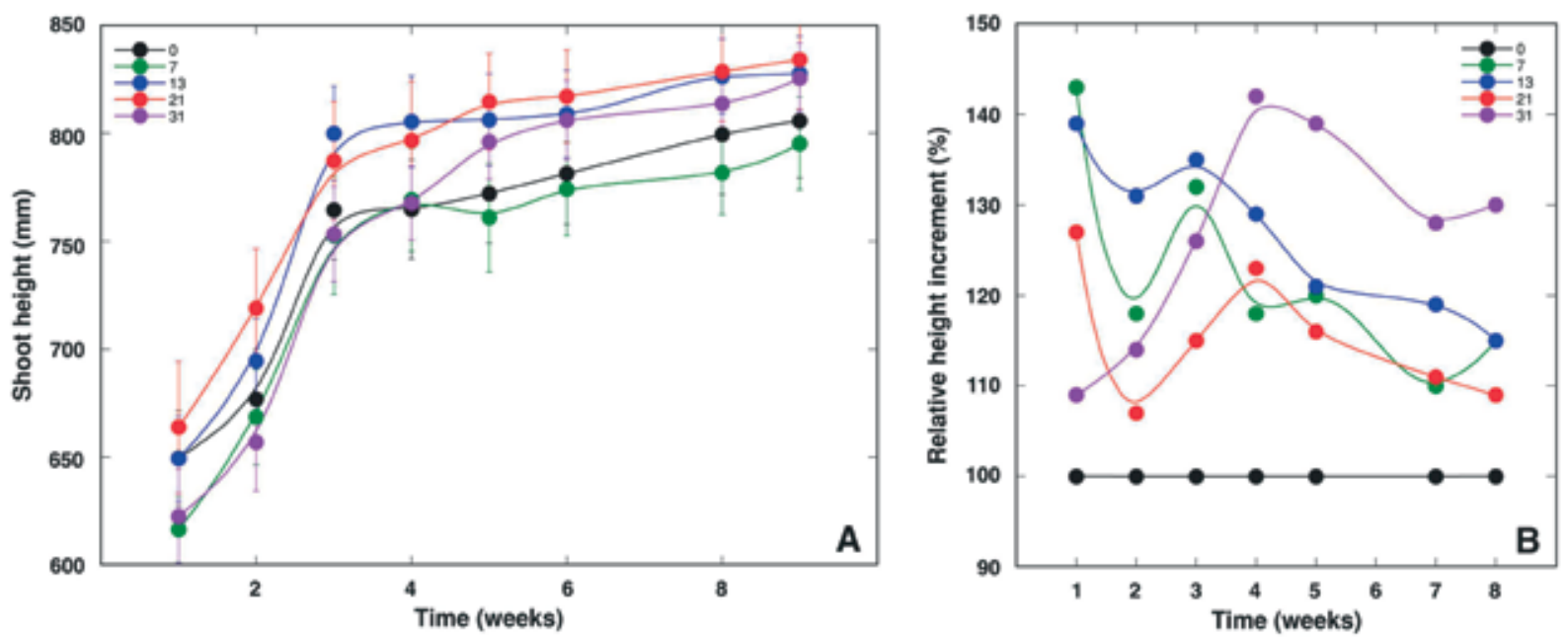

Fig. 5. Changes in shoot height in response to sand burial at various depths over time of Leymus arenarius plants (A). Data present the means $\pm \mathrm{SE}$ of ten individual plants. Changes in relative height of Leymus arenarius shoots due to sand burial at different depths over time (B). Data present the means of ten individual plants
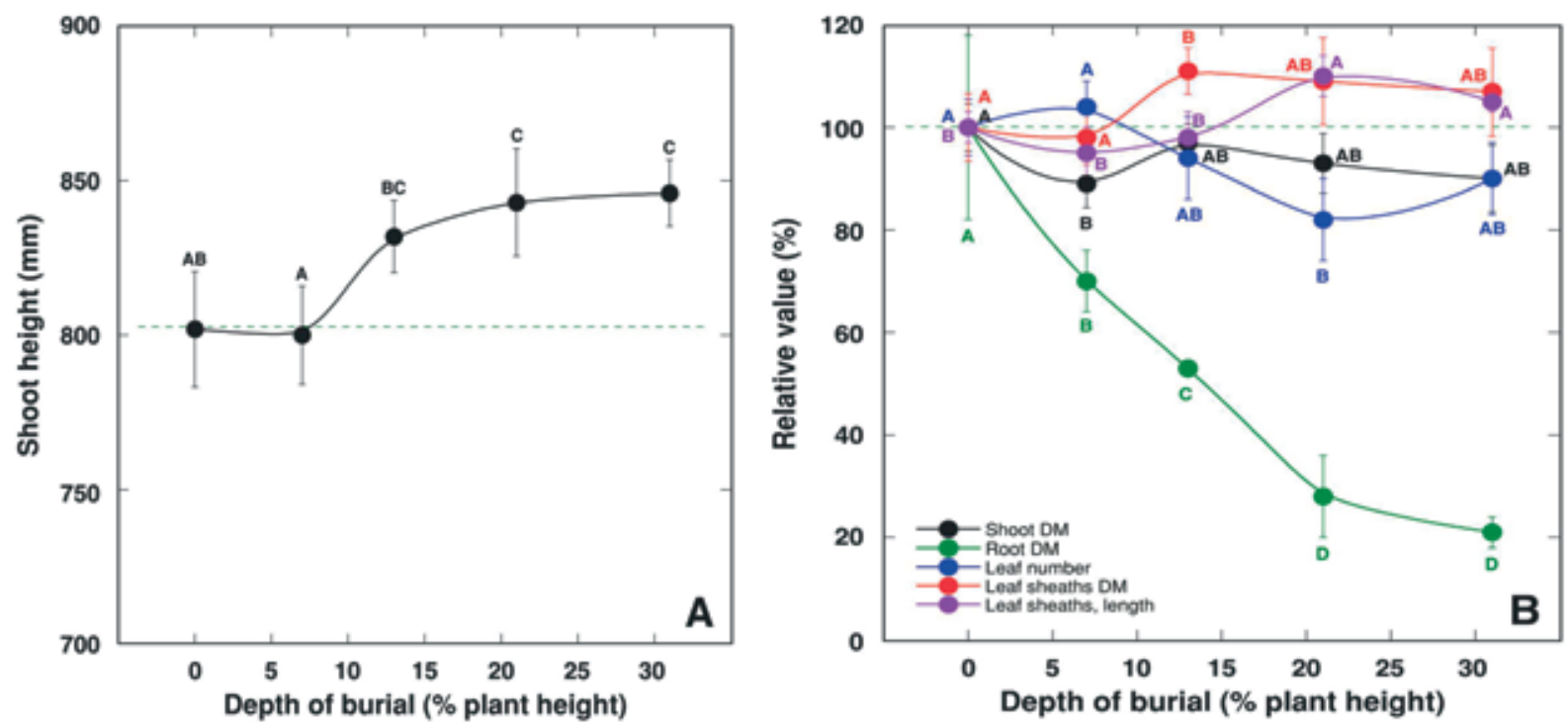

Fig. 6. Effect of sand burial depth on shoot height (A) and relative values of final morphological parameters (B) of Leymus arenarius plants. Data present the means $\pm \mathrm{SE}$ of ten individual plants. Different letters indicate statistically significant differences

um (WiLLIS, 1965). However, an alternative hypothesis has been raised that under stabilised dune conditions, burial-tolerant plants could not compete with newly appearing species with no sand burial tolerance (WATKInson et al., 1979). The role of biotic factors in the decline of dune-stabilising grass species in the absence of sand accretion has also been proposed (van der Putten et al., 1988; Seliskar \& Huettel, 1993; Boudreau \& Houle, 2001). Irrespective of fate of dune-building plant species in stabilised dunes, it has been indisputably established that the initial responses of sand dune-adapted species are significant growth stimulation (GILBERT \& RIPLEY, 2010).

As tolerance to sand accretion is primarily associated with an ability of an individual plant to grow out of the deposited sand layer and maintain photosynthetic function, differences in short to middle term in growth responses could provide comparative evidence for their ability to withstand sand burial conditions. Surprisingly, there are no reports available on 


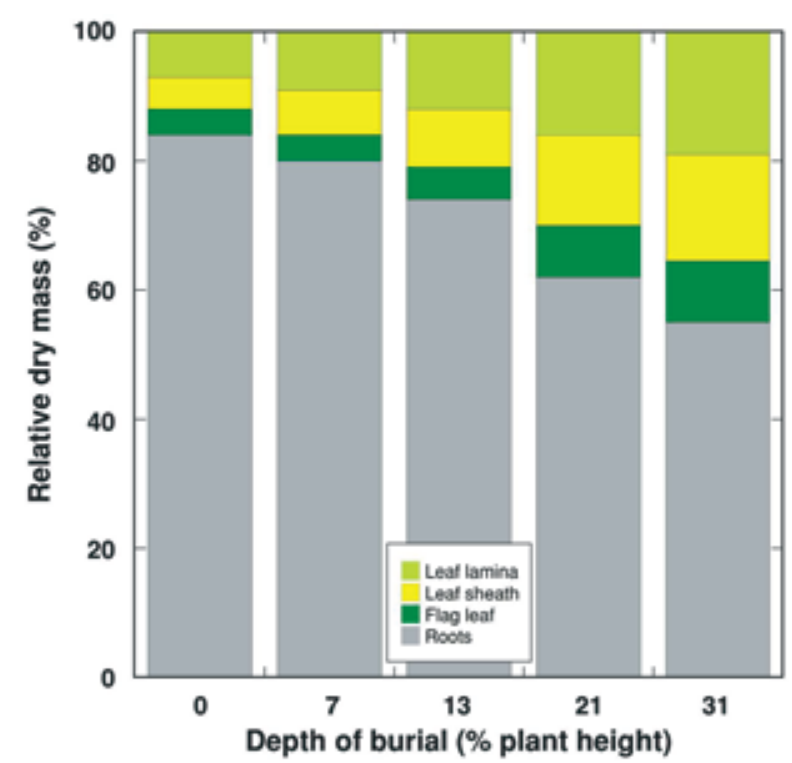

Fig. 7. Relative distribution of dry mass in different parts of Leymus arenarius buried in sand at different depths

experiments directly comparing these responses for $A$. arenaria and $L$. arenarius under controlled conditions. As pure quartz sand was used in the present investigation, any mineral nutrient effects through increased availability by sand burial could be ruled out.

In contrast to stress-like negative growth response of non-tolerant species to sand burial (SYKES \& WILSON, 1990), growth response to the sand burial of well-adapted dune-building plant species usually exhibits three phases in dependence on burial depth: (i) growth stimulation at low to moderate sand accretion intensity, (ii) absence of any morphological effect with further increasing intensity, and (iii) growth inhibition above some threshold burial limit. However, even for dune builders, particular limits of burial intensity for each phase can vary significantly (MAUn, 1998).

The seedlings of 10 -week-old $L$. arenarius showed increased resource allocation during glasshouse experiment to shoots without significant changes in total biomass, when subjected to gradual sand accretion 2 or $4 \mathrm{~cm}$ per week during seven weeks (GREIPSSON \& DAVY, 1996). In the present study, with single burial episode, but identical total burial depth, total shoot biomass of $L$. arenarius did not increase, and the root biomass decreased significantly, indicating a distribution of resources to shoots, but with low total carbon sequestration capacity in leaves, resulting in a lack of resources for shoot growth. In comparison, $A$. arenaria plants showed more pronounced resource acquisition capacity, with negative consequences for shoot development only at high burial intensities above $37 \%$ (Fig. 3B, C).

Differences in clonal underground architecture between the two species have been described, suggesting that low vertical growth of deeply buried rhizomes is responsible for generally lower burial tolerance of L. arenarius (HoBBs et al., 1983). In contrast, $A$. arenaria plants are capable of both horizontal and vertical rhizome growth, resulting in higher burial tolerance. Under buried conditions, A arenaria plants initiate the development of new roots near freshly buried leaf bases (WiLLis, 1965). Also, purely physiological differences between the two species related to dry matter and nitrogen allocation could have affected the observed differences in burial responses. Thus, it was shown that the growth of A. arenaria is mostly shoot-oriented in comparison to primarily root-oriented growth of Elymus mollis (syn. of Leymus mollis; PAVLIK, 1983a). An opposite response was indicated for $A$. breviligulata, which maintained root biomass and decreased allocation to elongation as a result of sand burial, while remobilising nitrogen from buried parts to leaves (BROWN \& ZINNERT, 2018). In a direct comparison between $A$. arenaria and $A$. breviligulata it has been shown that in contrast to the former, A. breviligulata is not able to develop vertically oriented rhizomes under conditions of sand burial (REIJERs et al., 2019).

Direct comparison of burial responses of the two species, $A$. arenaria and $L$. arenarius, in the present study, revealed somehow more complicated picture. First, shoot elongation response indeed showed a more pronounced positive effect for $A$. arenaria (up to $24 \%$ shoot height increase at $37 \%$ burial intensity, Fig. 3A) in comparison to that of $L$. arenarius (up to $6 \%$ shoot height increase at $31 \%$ burial intensity, Fig. 6A), and for the latter, the response did not depend on the depth of the accreted sand layer. Second, in contrast to what can be expected, L. arenarius plants showed an extreme degree of resource reallocation from roots to leaves in buried plants (Figs 6B, 7), but buried $A$. arenaria plants allocated resources to both shoots and buried roots at moderate burial intensity (up to $20 \%$ ), but mostly to buried roots to sustain 
clonal expansion at severe burial intensity (more than 30\%) (Figs 3C, 4). It is notable that under control conditions, root biomass of $A$. arenaria plants was about $30 \%$ of the total biomass (Fig. 4), but that of $L$. arenarius plants more than $80 \%$ (Fig. 7).

It seems that the threshold value for single-dose burial intensity for $A$. arenaria can be $37 \%$, but that for $L$. arenarius could not be easily established, due to low maximum limit of burial intensity used as well as clearly negative root growth response even at the lowest burial intensity. There is no doubt that gradual sand accretion as used in other studies (GREIPSSON \& DAVY, 1996) would result in a relatively higher burial intensity of the studied species, more resembling that under natural conditions. Moreover, a particular disparity between the results of the present experiments and these from other studies could be related to possible genetic differences of the plant material used as well as to variation in experimental conditions, mainly, when experimental manipulation by burial was performed under field conditions.

Consequently, with $A$. arenaria accumulating relatively more biomass in shoots and $L$. arenarius in roots under non-buried conditions, apparent differences found between $A$. ammophila and $L$. arenarius in sand burial responses (stimulation of growth of both parts for the first and translocation of resources from roots to shoots for the second species), are related to both morphological and physiological factors: spatial organisation of rhizome development and resource allocation towards leaf growth. From the other hand, dune building ability of the particular grass species is directly related to these differences in addition to simple burial tolerance. Due to differences in clonal architecture, A. arenaria plants can support the formation of relatively steep dunes, while dunes built by $L$. arenarius plants could be significantly wider, but lower.

It can be concluded that while both dune-building grass species $A$. arenaria and $L$. arenarius show positive shoot growth response to moderate sand burial, differences in individual responses at morphological and physiological level indicate the existence of different genetically-based adaptation strategies. This type of information could be useful for measures of practical dune conservation as well as habitat restoration needs.

\section{ACKNOWLEDGEMENTS}

The study was supported by the University of Latvia project "Functional diversity of ecosystems and their contribution to ecosystem services II" (UL No. ZD2016/AZ103).

\section{REFERENCES}

Bond T.E.T., 1952: Biological Flora of the British Isles. Elymus arenarius L. - Journal of Ecology, 40: 217-227.

Boudreau S., Houle G., 2001: The Ammophila decline: A filed experiment on the effects of mineral nutrition. - Ecoscience, 8: 392-398.

Brown J.K., ZinNERT J.C., 2018: Mechanisms of surviving burial: Dune grass interspecific differences drive resource allocation after sand deposition. Ecosphere, 9: e02162.

Ciccarelli D., Bacaro G., 2016: Quantifying plant species diversity in coastal dunes: a piece of help from spatially constrained refraction. - Folia Geobotanica, 51: 129-141.

Fidalgo F., Santos A., Pimenta S., Marques J., HonRado J., 2014: Regional environmental gradients influence ecophysiological responses of dominant coastal dune plants to changes in local conditions. - Journal of Coastal Research, 30: 893-903.

Gilbert M.E., Ripley B.S., 2010: Resolving the differences in plant burial responses. - Austral Ecology, 35: 53-59.

Gilbert M.E., Pammenter N.W., Ripley B.S., 2008: The growth responses of coastal dune species are determined by nutrient limitation and sand burial. - Oecologia, 156: 169-178.

GRAY A.J., 1985: Adaptation of perennial coastal plants: with particular reference to heritable variation in Puccinellia maritima and Ammophila arenaria. - Vegetatio, 61: 179-188.

Greipsson S., Davy A.J., 1994: Leymus arenarius. Characteristics and uses of a dune-building grass. - Icelandic Agricultural Sciences, 8: 4150.

Greipsson S., Davy A.J., 1996: Sand accretion and salinity as constraints of the establishment of Leymus arenarius for land reclamation in Iceland. Annals of Botany, 78: 611-618. 
Hobbs R.J., Gimingham C.H., Band W.T., 1983: The effects of planting technique on the growth of $\mathrm{Am}$ mophila arenaria (L.) Link and Lymus arenarius (L.) Hochst. - Journal of Applied Ecology, 20: 659-672.

Huiskes A.H.L., 1979: Biological Flora of the British Isles. Ammophila arenaria (L.) Link (Psamma arenaria (L.) Roem et Schult.; Calamgrostis arenaria (L.) Roth). - Journal of Ecology, 67: 363-382.

IEvinsh G., 2006: Biological basis of biological diversity: physiological adaptations of plants to heterogeneous habitats along a sea coast. - Acta Universitatis Latviensis, 710: 53-79.

Imbert E., Houle G., 2000: Ecophysiological differences among Leymus mollis populations across a subarctic dune system caused by environmental, not genetic, factors. - New Phytologist, 147: 601-608.

Keijsers J.G.S., De Groot A.V., Riksen M.J.P.M., 2015: Vegetation and sedimentation on coastal foredunes. - Geomorphology, 228: 723-734.

LAIME B., 2013: 2120 Shifting dunes along the shoreline with Ammophila arenaria (white dunes). In: Auninš̌ A. (ed.), European Union Protected Habitats in Latvia. Interpretation Manual. - Riga, Latvian Fund for Nature, Ministry of Environmental Protection and Regional Development, 73-75 p.

Maun M.A., 1998: Adaptations of plants to burial in coastal sand dunes. - Canadian Journal of Botany, 76: 713-738.

Maun M.A., Perumal J., 1999: Zonation of vegetation on lacustrine coastal dunes: effects of burial by sand. - Ecology Letters, 2: 14-18.

PAVLIK B.M., 1983a: Nutrient and productivity relations of the dune grasses Ammophila arenaria and Elymus mollis. II. Growth and patterns of dry matter and nitrogen allocation as influenced by nitrogen supply. - Oecologia, 57: 233-238.

Pavlik B.M., 1983b: Nutrient and productivity relations of the dune grasses Ammophila arenaria and Elymus mollis. III. Spatial aspects of clonal expansion with reference to rhizome growth and the dispersal of buds. - Bulletin of the Torrey Botanical Club, 110: 271-279.
Provoost S., Jones M.L.M., Edmondson S.E., 2011: Changes in landscape and vegetation of coastal dunes in northwest Europe: a review. - Journal of Coastal Conservation, 15: 207-226.

Reijers V.C., Siteur K., Hoeks S., van Belzen J., Borst A.C.W., Heusinkveld J.H.T., Govers L.L., Bouma T.J., Lamers L.P.M., van de Koppel J., vaN DER HeIde T., 2019: A Lévy expansion strategy optimizes early dune building by beach grasses. Nature Communications, 10: 2656.

Reijers V.C., Lammers C., de Rond A.J.A., HoetJES S.C.S., LAMERS L.P., VAN DER Heide T., 2020: Resilience of beach grasses along a biogeomorphic successive gradient: resource availability vs. clonal integration. - Oecologia, 192: 201-212.

SELISKAR D.M., 1994: The effect of accelerated sand accretion on growth, carbohydrate reserves, and ethylene production in Ammophila breviligulata (Poaceae). - American Journal of Botany, 81: 536-541.

Seliskar D.M., Huettel R.N., 1993: Nematode involvement in the dieout of Ammophila breviligulata (Poaceae) on the mid-Atlantic coastal dunes of the United States. - Journal of Coastal Research, 9: 97-103.

Sykes M.T., Wilson J.B., 1990: An experimental investigation into the response of New Zealand sand dune species to different depth of burial by sand. - Acta Botanica Neerlandica, 39: 171-181.

van der Putten W.H., Peters B.A.M., 1995: Possibilities for management of coastal foredunes with deteriorated stands of Ammophila arenaria (marram grass). - Journal of Coastal Conservation, 1: 29-39.

van der Putten W.H., van Dijk C., Troelstra S.R., 1988: Biotic soil factors affecting the growth and development of Ammophila arenaria. - Oecologia, 76: 313-320.

Watkinson A.R., Huiskes A.H.L., Noble J.C., 1979: The demography of sand dune species with contrasting life cycles. - In: JefFeries R.L., DAVy A.J. (eds), Ecological Processes in Coastal Environments: 95-113.- Oxford.

WiLlis A.J., 1965: The influence of mineral nutrients on the growth of Ammophila arenaria. - Journal of Ecology, 53: 735-745. 


\title{
PAKRANČIŲ KOPAS FORMUOJANČIŲ ŽOLINIŲ RŪŠIŲ AMMOPHILA ARENARIA IR LEYMUS ARENARIUS AUGIMO ATSAKAS İ JŲ PANARDINIMĄ SMĖLYJE
}

\author{
Gederts Ievinsh, Una Andersone-Ozola
}

\section{Santrauka}

Ammophila arenaria ir Leymus arenarius yra būdingos Baltijos jūros pakrančių kopų buveines formuojančios žolinès rūšys. Tyrimo tikslas buvo kontroliuojamose sąlygose palyginti abiejų augalų rūšių augimo atsaką i jų panardinimą smėlyje. Tiriami augalai buvo išauginti iš sẻklų, surinktų natūraliose pakrančių buveinèse. Augalai stiebėjimo stadijoje buvo persodinti $\mathfrak{i}$ atskirus konteinerius, kuriuose buvo panardinti smèlyje skirtinguose gyliuose ir toliau auginti automatizuotame šiltnamyje 9-11 savaičių. A. arenaria panardinimas ị smèli paskatino augalų ūglių augimą. Poveikis buvo akivaizdus praèjus dešimčiai dienų nuo bandymo pradžios ir buvo reikšmingesnis, esant gilesniam panardinimui smėlyje (46 ir 60\%). Ūglių ir šaknų masė padidèjo prie augalų panardinimo smèlyje $13 \%$. Didesnis panardinimo smèlyje gylis $(37,46$ ir 60\%) lèmè reikšmingą šaknų masès padidejjimą, tačiau ūglių biomasè žymiai sumažèjo, esant didžiausiam panardinimo intensyvumui $(60 \%)$. Tačiau nenustatyta reikšmingos L. arenarius ūglių pailgėjimo priklausomybės nuo jų panardinimo smėlyje intensyvumo. Tuo tarpu šaknų biomasè sumažèjo didejjant panardinimo smèlyje gyliui. Apibendrinant galima teigti, kad nors abi tirtos augalų rūšys parodè teigiamą ūglių augimo atsaką ì vidutinio intensyvumo panardinimą smèlyje, morfologiniai skirtumai parodè skirtingą jų prisitaikymo strategiją. 